\title{
Provision of Security Facilities and Security Personnel Service Delivery in Universities in Cross River State, Nigeria
}

\author{
Comfort R. Etor ${ }^{1}$, Eno Etudor-Eyo ${ }^{2}$ \& Godfrey E. Ukpabio ${ }^{1}$ \\ ${ }^{1}$ Department of Educational Administration and Planning, University of Calabar, Calabar, Nigeria \\ ${ }^{2}$ Department of Curriculum Studies and Educational Management, University of Uyo, Uyo, Nigeria \\ Correspondence: Eno Etudor-Eyo, Department of Curriculum Studies and Educational Management, University of \\ Uyo, Uyo, Nigeria.
}

Received: November 9, 2019

Accepted: December 22, 2019

Online Published: April 18, 2020

doi:10.5539/ies.v13n5p125

URL: https://doi.org/10.5539/ies.v13n5p125

\begin{abstract}
The study examined provision of security facilities and security personnel service delivery in Universities in Cross River State, Nigeria. Three research questions and one hypothesis guided the study. The ex-post facto design was adopted for the study. The population of the study comprised 440 security personnel while the sample size was 400 security personnel. Two researchers developed and validated instruments entitled "Provision of Facilities Questionnaire (POFQ) and Security Personnel Service Delivery Questionnaire (SPSDQ) were used for data collection. The reliability estimates of the instrument were determined using Cronbach Alpha Analysis and the coefficients of 0.80 and 0.83 were obtained. Descriptive statistics was used to answer the research questions while Pearson Product Moment Correlation was used to test the hypothesis at 0.05 level of significance. The finding of the study showed that there exist a disparity in the provision of security facilities in the institutions with the minimum provision of 11.10 and maximum of 26.00 facilities by State and Federal Universities respectively. The level of provision of security facilities in the two institutions studies indicated two levels of inadequate and moderate with a grand mean of 2.5135 and standard deviation of .92773 . The level of security service delivery in the Universities in Cross River State depend on the level of availability of security facilities for use by security personnel is evident that there are three levels of security service delivery in Universities. The finding of the study also revealed that there is a significant relationship between provision of security facilities and security personnel service delivery. Based on the findings, it was recommended that the administrators should provide adequate security facilities such as hand guns, CCTV, tear gas, bullet proof vests and so on for effective security personnel service delivery.
\end{abstract}

Keywords: security facilities, security personnel, service delivery, universities

\section{Introduction}

From time immemorial man has been using security facilities to protect himself from attacks. The primitive man used stones and clubs to defend himself whenever he was attacked either by wild animals or fellow humans. There are many facilities that are used to secure homes and organizations on daily basis. Organizations like the universities need adequate protection from terrorists, vandals, kidnappers and other crime prone situations that are gaining grounds in our society. The provision of adequate security facilities in universities is the duty of the administrator through the chief security officer and the entire security department. This is to ensure that the security officers are well equipped with the necessary tools needed for securing the university premises and its environs at all times.

The university as a citadel of learning encompasses a large community of people from various parts of the world; it is an arena where individuals go in quest for knowledge. The university is not only a knowledge factory but also a dispenser of knowledge. The position of the University in the society attracts many people to the institution for various reasons. Some come to acquire knowledge, some to create and dispense knowledge, some to administer, while others are there to provide goods and services to the entire school community. In a setting of this nature, where there are so many people with individual differences, aims, objectives and goals, there is bound to be security challenges hence the need for the establishment of security department in all universities. As pointed out by Etor and Ukpabio (2017), securing lives and property in our universities is very crucial without which the school goals may not be attained. 
Securing property in institutions of this magnitude requires a lot of planning, organizing, coordinating and controlling relevant human and material resources available for quality security service delivery. The work of the security department in any University is not an easy one, because security involves making sure that life and property in a particular place are protected from danger or destruction. Security entails the provision of safety in the organization. To ensure the achievement of the stipulated aims, objectives and goals of the universities, security activities must be put in place to ensure proper functioning of the entire system.

Bassey (2009) defined security as measures put in place to ensure that things work well to one's advantage and which makes sure that nothing goes wrong with what affects one's personal or group interest in whatever way. He further stated that security can also be perceived as "an innovative, systematic and proactive process for the determination of danger and the protection of persons and property from harm of any kind, whether man-made or by nature" (p.6). This implies firstly, that security network must be innovative, must involve some principles that are characterized by new ideas and devices that are germane to the dynamic nature of the society. Secondly, security is systematic in nature and constitutes interrelated body of ideas, methodical procedure and thoroughness. Finally, security is being perceived as preventive because it should be able to anticipate and forestall in advance any form of harm or threat to life and property. According to Francis (2009) security is generally about the condition of feeling safe from harm or danger. It is about survival and the conditions of human existence. This safety may be guaranteed by the provision of certain basic facilities like guns, bullet proof vests, and first aid.

Jain and Rao (2011) associated security with provision against theft and entry of unauthorized persons, into work premises, and is essential for preventing sabotage. The duties of the security personnel in the University are multifaceted; hence they are engaged to work day and night. As pointed out by Akpan (2011) their duties include making sure that buildings are secured at the close of work as well as in the morning. They are to ensure that there was no illegal entry in the night and no unauthorized person gained entry into the premises. They also patrol the entire university environment by day and by night to ensure the safety of lives and property, because as pointed out by Tepperman, Curtis, and Kwan (2007) criminal activities can have negative effect on people's health, safety and sense of well-being. Anyone that is constantly afraid because of insecurity may have health challenges due to fear of the unknown. Moreover, modern terrorism, as pointed out by Akpuru-Aja (2009) is a paradigm shift from hijacking cases to payment of ransom to secure the release of victims who are often subjected to inhuman treatment and torture, which in some cases have resulted in the death of the victims.

The true tests of good security as reiterated by Bassey (2009) is when lives are safe, burglaries prevented, robberies foiled and frauds are curbed or curtailed. The work of the security personnel in an organization like the University where cases of vandalism, cultism, theft and so on, are replete require a lot of basic and relevant working tools and facilities to enhance their effective job performance. This is because their job involves high risks on their own lives and that of those they are hired to protect. To this end, some of the facilities security personnel need as outlined in Security Guard (2015-2018) includes flash light which is very necessary while patrolling in the night or sniffing out dark places in order to sight unauthorized persons or movement as well as dangerous animals and moving creatures like snakes and so on. Other security facilities are batons, boots, security belts, pepper spray or tear gas, cell phones, walkie-talkies, digital cameras, knives, robes, rain coats, hand-cuffs, whistles and so on. When security facilities are not adequate, the service delivery of security personnel may be greatly hindered. That may have been the reason some security officers with inadequate facilities ran for their lives when one of the institutions was invaded by hoodlums in 2015 and 2017. This is to say that security service delivery in our institutions is not properly carried out by the personnel. Some of them often run away leaving the victims to face the challengers.

Bassey (2014) observed that violence carried out by external perpetrators can affect staff and all others who do various businesses in organizations such as the University. Cases of theft are often reported around campuses without the perpetrators being arrested. These are clear indicators that the security officers are not doing their job effectively. Jain and Roa (2011) outlined security infrastructure to include but not limited to perimeter fence or walls of premises, lighting for security alarm system, close circuit TV, communication systems of locks and keys and entry pass system. Bassey (2014) also pointed out that surveillance technology exemplified by close circuit television (CCTV) is almost invaluable in the prevention of robbery and terrorism. These facilities can hasten the work of security personnel if provided in our institutions. They can motivate and encourage the staff to be serious in tackling security threats without fear. From the foregoing, the researchers wonder whether service delivery of security officers relate to provision of facilities.

Very few empirical work on provision of security facilities exist. These two were reviewed based on their relevance to this study. Ominyi (2017) carried out a study on security personnel management and service 
delivery in universities in Benue State. The sample was made up of 847 respondents. Analysis of variance was used to test the hypotheses. The findings of one of the hypotheses showed a significant influence of security personnel facilities on service delivery in Universities. The findings also revealed poor maintenance of security personnel and poor facilities provision.

Murunga (2014) studied the effects of working conditions of private security guards on service delivery. The population comprised 3000 security force, security guards, 200 management staff and over 400 clients all based in Nairobi country. Cluster sampling was adopted where 3 cluster of guards, police management and clients were selected. Simple random sampling technique was used to sample 150 guards, 20 management staff and 25 clients. Questionnaire was used to collect primary data. Some of the findings showed that most guards had left private security companies due to low wage and salaries, poor work environment, limited or no promotion, working for long hours and poor working tools which expose them to more dangers.

\section{Statement of the Problem}

The task of security service delivery is a hard one, especially in this era of global terrorism in cities and the workplaces, including the Universities. The security of lives and property in organizations like the Universities are the sole duty of their security personnel. In a situation where these security personnel are ill-equipped with the relevant security apparatus to perform their duties, their lives would be endangered which may result in low performance and job dissatisfaction. Security personnel in the universities in Cross River State, Nigeria do not seem adequately motivated to perform their duties. In one of the institutions, these personnel found it difficult to engage or overcome invaders on their campus because their weapons could not match with that of their opponents. They lack basic facilities such as boots, pepper spray, digital camera, close-circuits television, bullet-proof vests and guns to enable them function effectively. The problem of this study therefore, is to find out how non-provision of security facilities affects effective personnel security delivery in Cross River State Universities.

\subsection{Research Questions}

i. What is the disparity in the provision of security facilities for service delivery?

ii. What is the level of provision of security facilities?

iii. What is the level of security service delivery in universities in Cross River State?

\subsection{Research Hypothesis}

There is no significant relationship between provision of facilities and security service delivery in universities of Cross River State.

\section{Theoretical Framework}

This study is anchored on F. W. Taylor's Scientific Management theory (1911). The theory is concerned with the management of workers and work to enhance work performance or service delivery. One of the major concerns of Taylor was the provision of the relevant working tools (facilities) and training workers on their effective use for improved work performance. He therefore concentrated on work-study and motion study to enhance effective training as well as time measurement (timing) for every piece of work by every worker. He also advocated for improved monetary rewards for workers as incentives for improved performance

Peretomode (2012) presented the following as the roles of management in the application of scientific management approach in work situations

i. The development of a true science to replace the intuitive or rule-of-thump of doing each person's work in the organization. He felt that using the technique of Time and Motion study it was possible to determine the one best way to do a job.

ii. The scientific training, education and development of the workers

iii. The workers should be given such standardized conditions, carefully controlled working environments and standardized appliances as this will enable them to accomplish their tasks with certainty

iv. Pay should be directly tied to productivity. The worker should be sure of high pay when he accomplishes his task (p.69-70)

This theory is relevant to this study because security personnel in the Universities should be constantly trained, provided with appropriate modern facilities, provided with secure working environments and appropriately rewarded financially and with other non-financial rewards in view of the risky nature of their job. 


\section{Methodology}

The research design used in this study was the ex-post-facto design. This design is a systematic empirical inquiry in which the researchers do not have direct control of independent variable since their manifestations had already occurred. The population of the study comprised 440 security personnel in University of Calabar and Cross River University of Technology. The census sampling technique which allows the usage of the whole population was used for this study. This is used when the population is sizeable and can be effectively handled by the researchers. The sample size for this study therefore was 440 security personnel gathered from the two sampled universities.

The two instruments used for the study were tagged Provision of Facilities Questionnaire (POFQ) and Security Personnel Service Delivery Questionnaire (SPSDQ). The instruments were developed and validated by the researchers. The reliability estimates of the instrument were determined using Cronbach Alpha Analysis and the reliability coefficient of 0.80 for (POFQ) and 0.83 for (SPSDQ) were obtained. POFQ sought information on provision of facilities while SPSDQ sought information on service delivery. POFQ comprised 7 items while SPSDQ consisted of 14 items. Each item was weighted on a 4-point rating scale which ranged from Strongly Agree (SA), Agree (A), Disagree (D) and Strongly Disagree (SD).

The instruments were administered to security personnel in the two universities with the help of two assistants who were briefed on how to guide the respondents to tick the responses. The questionnaire copies were retrieved by the assistants after a few days. Four hundred (400) questionnaire copies were correctly filled and returned signifying a $91 \%$ return rate. Descriptive statistics and Pearson Product Moment Correlation were used to analyze the data.

Analysis of data involved both descriptive and inferential tools. Means and standard deviation were used to analyze the research questions, while Pearson Product Moment Correlation was used for testing the hypothesis. A decision rule was made for the research questions. A cut-off point of 2.50 was established as the mean result for the two research questions. A mean score below 2.45 was regarded as inadequate, a mean score of $2.50-2.99$ was regarded as moderate while a mean score of 3.00 and above was regarded as highly adequate accordingly.

\section{Result}

Research Question One: What is the disparity in the provision of security facilities for service delivery?

Table 1. Mean difference of the disparity in the provision of security facilities for service delivery

\begin{tabular}{ccccc}
\hline Provision of security facilities & $\mathrm{N}$ & Mean & Mean difference & Std. Deviation \\
\hline Federal University & 220 & 18.8175 & 3.5117 & 4.4659 \\
State University & 180 & 15.3058 & & 3.7358 \\
\hline
\end{tabular}

Result in Table 1 showed the mean and standard deviation of provision of facilities for service delivery for the two Universities under consideration. The instruments were administered to security officers in the two Universities. The mean (18.8175) and standard deviation (4.4659) for Federal university were higher than the mean (15.3058) and standard (3.7358) for State University respectively. The mean difference between the two universities is 3.5117 , implying disparity in the provision of security facilities for service delivery.

Research Question Two: What is the level of provision of security facilities?

Table 2. Rating of the availability of security facilities for quality service delivery in universities in Cross River State, Nigeria

\begin{tabular}{lcccc}
\hline Facilities & $\mathrm{N}$ & Mean & Std. Dev. & Decision \\
\hline Provision of hand guns & 400 & 2.6225 & .95513 & Moderate \\
Provision of boots & 400 & 2.4450 & .89385 & Inadequate \\
Access to tear gas & 400 & 2.6475 & .95158 & Moderate \\
Provision of first aid & 400 & 2.7675 & .95694 & Moderate \\
Provision of bullet proof vests & 400 & 2.4950 & .85838 & Inadequate \\
Walkie talkies & 400 & 2.6400 & .90135 & Moderate \\
CCTV equipment & 400 & 1.9775 & .97692 & Inadequate \\
Grand mean & & 2.5135 & .92773 & \\
\hline
\end{tabular}


Table 2 showed that provision of security facilities such as boots, bullet proof vests and CCTV with mean scores of $2.4450,2.4950$ and 1.9775 respectively were rated as being inadequate by the respondents. But the overall mean of 2.5135 on the provision of security facilities were regarded as moderate. This means that the available security facilities need to be upgraded for quality service delivery in the Universities.

Research Question Three: What is the level of security service delivery in universities in Cross River State?

Table 3. Rating of the level of security personnel service delivery in universities in Cross River State

\begin{tabular}{lcccc}
\hline Rating of service delivery & $\mathrm{N}$ & Mean & Std. Dev. & Decision \\
\hline Always everywhere on campus & 400 & 2.0825 & 1.01896 & Inadequate \\
Always at various gates & 400 & 3.5225 & .53405 & Highly adequate \\
Protection against negative occurrence & 400 & 2.2675 & .83827 & Inadequate \\
All being able to detect crime & 400 & 2.6850 & .93700 & Moderate \\
Few being able to detect crime & 400 & 2.7500 & .94855 & Moderate \\
Few being very unserious at duty post & 400 & 2.6200 & .90424 & Moderate \\
Very few found on duty post & 400 & 2.6525 & .91039 & Moderate \\
Foiling security challenges & 400 & 2.9449 & .91989 & Moderate \\
Walking around offices and classes & 400 & 2.7075 & .89943 & Moderate \\
Checking of non-university members & 400 & 2.5700 & .91772 & Moderate \\
Interrogation of people & 400 & 2.0775 & .78934 & Inadequate \\
Reporting disorders to authorities & 400 & 2.6175 & .91558 & Moderate \\
Protection of formal gathering & 400 & 2.7475 & .92784 & Moderate \\
Protection against vandalization & 400 & 2.6200 & .90976 & Moderate \\
Grand mean & & 2.6332 & & \\
\hline
\end{tabular}

Table 3 showed that the rating of availability of security personal presence for service delivery on campus, protection against negative occurrence on campus and interrogation of suspicious people with the mean scores of $2.0825,2.2675$ and 2.0775 respectively were rated as being inadequate by the respondents. But the overall mean of 2.6332 on the security personnel services delivery were regarded as moderate and presence of security personnel at the gates was regarded as highly adequate.

Hypothesis One: There is no significant relationship between provision of facilities and security service delivery in Universities of Cross River State.

Table 4. Results of Pearson Product Moment Correlation Coefficient Analysis (r) of the relationship between provision of securities facilities and service delivery of security personnel in Universities in Cross River State

$\mathrm{P}<.05$, Critical $\mathrm{r}=.139$

\begin{tabular}{ccccc}
\hline Variables & $\mathrm{N}$ & Mean & Std. deviation & $\mathrm{r}$ \\
\hline Provision of Security Facilities & 400 & 17.5950 & 2.37172 & \\
Service delivery & 400 & 36.8521 & 3.48445 & .880 \\
\hline
\end{tabular}

Table 4 showed that the observed correlation coefficient of .88 was greater than the critical value of .087 needed for significance at .05 alpha level with 398 degrees of freedom. With this result, the null hypothesis was rejected. This implies that there is a significant relationship between provision of security facilities and service delivery in Universities in Cross River State. The finding depicts that the more facilities provided to security personnel the more they are capable of providing effective security service delivery.

\section{Discussion of Findings}

Research question one: The result in Table 1 showed a disparity in the provision of security facilities in the institutions studied with mean difference of 3.5117. This result indicated differences in the provision of security facilities in the two institutions. This means that the State University cannot compete favorably with the Federal University in the provision of security facilities because the funding of state and federal Universities are not the same and that has implications for provision of security facilities in each institutions. The result showed that 
service delivery cannot be the same as evidenced in the mean values of 15.3058 for state and 18.8175 for Federal Universities respectively (Table 1).

Research question two:

The level of provision of security facilities in the two institutions studied indicated two levels of inadequate and moderate with grand mean of 2.5135 and standard deviation of .9277 (Table 3). This implies that each University should improve in their current provision of security facilities in order to enhance security personnel service delivery.

Research question three:

The level of security service delivery in Universities in Cross River State, Nigeria depends on the level of availability of security facilities for use by security personnel. In Table 4, it is evident that there are three levels of security service delivery in Universities which are highly adequate, moderately adequate and inadequate. This implies that either the number of security personnel is highly adequate, moderate and inadequate or the reverse is their service delivery. Consequently, the need for provision of more security personnel becomes obvious as well as the supervision of security personnel at work to ensure effective security personnel service delivery in Universities in Cross River State, Nigeria.

The result of the hypothesis revealed that provision of security facilities significantly relate to security personnel service delivery in universities in Cross River State. This is because the availability of relevant and adequate security facilities such as hand guns, booths, tear gas, first aid, bullet proof vests, walkie-talkie, and CCTV would enhance proper usage and effective service delivery by security personnel in the universities. The finding is consonance with the finding of Ominyi (2017) whose result revealed a significant relationship between availability of security facilities and security personnel service delivery. The finding of this study also showed that where the provision of facilities provided was inadequate; the security personnel were not able to perform their duties effectively.

Conversely, where the security personnel were provided with relevant and adequate facilities, their service delivery were adequate. A study by Murunga's (2014) on the effect of working conditions of private security guards on service delivery in Kenya showed that low wage and salary, poor work environment, limited or no promotion, long working hours and poor working tools that exposes security personnel to more danger forced them to leave the organization. Ideally, poor work tools or inadequate facilities can actually expose these set of workers to serious danger because they may not be capable of repressing any attack properly, and that will engender their lives. That was why they refused to show up in one of the institutions when serious cases came up in 2015 and 2017 respectively. Procurement of modern security facilities can scare hoodlums and miscreants from the institutions because they will be afraid of causing trouble or attacking the property since they know that the security personnel are equipped to handle any issue without fear.

\section{Conclusion}

Every university's goal is to train and educate the citizenry for self, societal and national development. This cannot be achieved if the institution is not safe for effective teaching and learning. In this era of terrorism and unrest on campuses, it is proper for the administrators to equip the security personnel with adequate facilities so that they can carry out their work creditably.

\section{Recommendations}

Based on the findings the following recommendations were made:

1) Administrators of universities should ensure the provision of adequate security facilities such as hand guns, CCTV, tear gas, bullet proof vests and so on, for effective security service delivery.

2) There should be adequate supervision of the services delivered by the security personnel to ascertain that they are doing their jobs to secure lives and properties on campus.

3) The security personnel who run away when they should be helping the victims should be warned initially, if the behavior is repeated they should be queried and in the event of reoccurrence, the unrepentant personnel should be shown the way out of the system.

\section{References}

Akpan, C. P. (2011). Fundamentals of School Business Management. Princhoice Konsult, Calabar, Nigeria.

Akpuru-Aja, A. (2009). Basic Concept of Conflict. In M. Ikejiani-Clark (Ed.), Peace Studies and Conflict Resolution in Nigeria (pp. 12-35). Spectrum Books, Ibadan, Nigeria. 
Bassey, R. (2014). Social-situational Crime Prevention Strategies. In R. Bassey, E. Alemika, \& O. Tamgban (Eds.), Policing and Crime Prevention in Nigeria (pp. 423-442). African Council on Narcotics and Crime Prevention, Jos, Nigeria.

Bassey, R. E. (2009). General Principles of Security. The African Council on Narcotics and Crime Prevention, Jos, Nigeria.

Bassey, S. C. (2014). Prevention and Control of Organization Violence. In R. Bassey, E. Alemika, \& O. Tamgban (Eds.), Policing and Crime Prevention in Nigeria (pp. 331-342). African Council on Narcotics and Crime Prevention, Jos, Nigeria. 33

Etor, C. R., \& Ukpabio, G. E. (2017). Security Personnel Training and Service Delivery in Universities in Cross River State, Nigeria. Education for today, 13(2), 101-106

Francis, D. J. (2009). Peace and Conflict Studies: African Overview of Basic Concepts. In S. G. Best (Ed.), Introduction to Peace and Conflict Studies in West Africa (pp 15-34). Spectrum Books: Ibadan.

Jain, R. K., \& Rao, S. S. (2011). Industrial Safety Health and Environment Systems. Khanna Publishers: New Delhi.

Murunga, P. L. (2014). The Effects of Working Condition of Private Security Guards on Service Delivery: Case of Secure Force Security Company Nairobi County. A Thesis in Security Management and Police Studies of Humanities and Social Science of Kenyatta University, Kenya.

Ominyi, J. I. (2017). Security Personnel Management and Service Delivery in Universities in Cross River State, Nigeria (Unpublished M.Ed. Thesis in Educational Administration and Planning). University of Calabar, Nigeria.

Peretomode, V. F. (2012). Theories of Management: Implications for Educational Administration. Benin City: Justice JECO Printing and Publishing Global

Security Guard (2015-2018). Security Equipment Gear. Retrieved from https://www.security.com

Tepperman, L., Curtis, J., \& Kwan, A. (2007). Social Problems: A Canadian Perspective (2nd ed.). Oxford University Press, Canada.

\section{Copyrights}

Copyright for this article is retained by the author(s), with first publication rights granted to the journal.

This is an open-access article distributed under the terms and conditions of the Creative Commons Attribution license (http://creativecommons.org/licenses/by/4.0/). 